\begin{tabular}{|c|c|}
\hline$x_{12}^{2}$ & Malaysian Journal of Social Sciences and Humanities (MJSSH) \\
\hline Malaysian Journa of & Volume 6, Issue 2, February 2021 \\
\hline$(n 00-\operatorname{ssn})$ & e-ISSN: 2504-8562 \\
\hline & $\begin{array}{l}\text { Journal home page: } \\
\text { www.msocialsciences.com }\end{array}$ \\
\hline
\end{tabular}

\title{
Kesan Pembelajaran Reflektif menerusi Blog bagi Tajuk Teorem Pitagoras ke atas Pencapaian dan Motivasi Murid Tingkatan Empat
}

\author{
Nur Lidiana Edyanti Binti Mohd Esa1, Zaidatun Tasir² \\ ${ }^{1}$ Sekolah Menengah Kebangsaan Taman Nusajaya \\ ${ }^{2}$ Fakulti Sains Sosial \& Kemanusiaan, Universiti Teknologi Malaysia (UTM) \\ Correspondence: Zaidatun Tasir (p-zaida@utm.my)
}

\begin{abstract}
Abstrak
Kajian ini bertujuan untuk mengenal pasti kesan pembelajaran blog reflektif bagi tajuk Teorem Pitagoras ke atas pencapaian dan motivasi murid tingkatan 4 . Seramai 30 orang murid tingkatan empat yang dipilih berdasarkan teknik persampelan rawak mudah terlibat dalam kajian ini. Instrumen kajian ini merupakan soal selidik motivasi dan ujian pencapaian. Semua dapatan dalam kajian ini dianilisis secara statistik inferensi iaitu ujian t sampel berpasangan dan Wilcoxon signed rank test melalui perisian IBM SPSS. Dapatan kajian ini menunjukkan bahawa terdapat hubungan yang signifikan antara penggunaan blog reflektif melalui kaedah inkuiri terhadap pencapaian dan motivasi murid. Penggunaan blog didapati mempengaruhi peningkatan dalam pencapaian dan motivasi pembelajaran topik teorem pitagoras dalam kalangan murid. Kajian ini telah memberikan sumber maklumat kepada guru matematik bagaimana caranya untuk melaksanakan proses pengajaran dan pembelajaran melalui penggunaan blog reflektif dengan berkesan.
\end{abstract}

Kata kunci: blog reflektif, teorem pitagoras, pencapaian murid, motivasi murid

\section{The Effects of Reflective Learning through Blog for Phitagoras Theorem on Form Four Students' Achievement and Motivation}

\begin{abstract}
This study aims to determine whether there is an effect of using reflective blog for learning Phytagoras Teorem towards form 4 students' achievement and motivation. A total of 30 form four students selected through simple random sampling technniques were involved in this study. The research instrument are a motivation questionnaire and an achievement test. The data of this study were analyzed using inferential statistics, which is paired sample t test and Wilcoxon signed rank test through IBM SPSS software. The findings of this study indicated that there is a significant relationship between the use of reflective blog through inquiry towards students' achievement and motivation. The use of blog has influenced the increment of student's performance and motivation in learning Phytagoras Theorem. The implication of this study provided information for the Mathematic teachers to implement and using reflective blog through inquiry effectively because of enhancing students' achievement and motivation.
\end{abstract}

Keywords: reflective blog, Phitagoras Theorem, student's achievement, student's motivation 


\section{Pengenalan}

Pendekatan menggunakan blog dalam bidang pendidikan merupakan satu alatan yang sering digunakan sebagai satu medium penyampaian maklumat kepada semua lapisan masyarakat (Ciampa \& Gallagher, 2015). Penggunaan blog sebagai satu cara untuk meningkatkan kemahiran dan kefahaman seseorang individu itu amat perlu bagi mengukuhkan lagi maklumat yang diterima oleh para pelajar. Apakah masalah yang dihadapi jika pengintegrasian blog dalam pendidikan tidak berfokus kepada matlamat yang ditetapkan? Kebanyakkan blog pendidikan pada masa kini adalah berteraskan kepada karya-karya penulisan dalam pelbagai bahasa. Justeru, blog pendidikan yang cenderung kepada tajuk yang lebih ilmiah seperti sains, matematik, teknologi, rekabentuk dan sebagainya pula jarang ditemui secara maya, dan hanya segelintir sahaja dan daripadanya tidak menetapkan pedagogi yang sesuai untuk mencetuskan proses pemikiran reflektif dalam sesuatu bidang yang khusus. Siapakah yang cenderung untuk menggunakan blog masa kini? Dewasa ini, blog merupakan satu medium maya yang bebas dan boleh diakses oleh sesiapa sahaja dimana-mana. Jika penggunaan blog pendidikan dapat diusahakan kepada peringkat yang lebih ilmiah dan berfokus, peluang untuk para pelajar memberikan sumbangan idea yang bernas dapat dikongsikan bersama.

Oleh itu, proses pembelajaran yang kukuh perlu dilaksanakan untuk meningkatkan kualiti dan taraf pendidikan seseorang. Apakah kaedah pengajaran dan pembelajaran yang dilihat sesuai untuk blog pendidikan beroperasi dengan baik tanpa menjejaskan konsep blog itu sendiri? Menurut Royer (2008), teknologi yang diterapkan dalam blog pendidikan semata-mata tidak mendatangkan manfaat kepada para pelajar kerana mereka tidak didedahkan tentang kebolehfungsian blog dengan lebih terperinci. Selain itu, sebagai seorang pendidik, kita perlu melihat dari skop perspektif yang berbeza untuk membantu meningkatkan pemikiran reflektif pelajar menerusi blog, bukan hanya sekadar pengitegrasian teknologi dalam bidang pendidikan malah lebih kepada proses pengajaran dan pembelajaran yang efektif. Kini, desakan perkembangan teknologi yang pantas menyebabkan pelbagai bahan pembelajaran kian meningkat. Justeru, pemikiran reflektif dilihat sesuai disemarakkan untuk menarik minat pelajar dalam suasana pembelajaran menerusi blog. Oleh itu, konsep pembelajaran tajuk teorem pitagoras menerusi kemahiran berfikir secara reflektif merupakan salah satu inovasi kepada pembelajaran menerusi blog sebagai medium pembelajaran yang efektif. Tujuan tajuk ini diipilih adalah berdasarkan kepentingan tajuk ini dalam pembelajaran Matematik di sekolah.

\section{Sorotan Literatur}

Pembelajaran konvensional telah mendominasi kaedah pengajaran dan pembelajaran matematik di sekolah sekian lamanya (Garcia \& Pacheco, 2013). Murid-murid hanya mendengar, mencatat isi pelajaran dan tidak memahami konsep kerana mereka hanya menghafal rumus semata-mata (Auster \& Wylie, 2006). Dalam situasi ini, murid diletakkan sebagai objek penerima bahan pelajaran daripada guru, manakala guru pula bertindak sebagai ejen pembelajaran serta tidak mampu membantu meningkatkan motivasi murid-murid. Guru-guru meletakkan diri mereka sebagai seorang yang mempunyai pengetahuan dan satu-satunya sumber ilmu. Guru hanya menyampai dan murid mendengar bagi memastikan kelangsungan proses pembelajaran. Pembelajaran ini hanya berpusatkan kepada guru dan searah semata-mata (McPherson, 2009). Dalam menangani masalah pendidikan matematik di sekolah, minat dan keinginan murid haruslah dicakna agar kemahuan untuk belajar dalam kalangan murid-murid ini meningkat dan lebih bermotivasi (McPherson, 2009). Penguasaan dan kefahaman untuk matematik akan menjadi mudah jika kemahuan dan keinginan untuk belajar Matematik itu tinggi dikalangan muridmurid (Stoyle \& Morris, 2017).

Menurut Thomas (2017), kajian berkaitan blog perlu memfokuskan kepada kaedah-kaedah pengajaran dan pembelajaran yang ada menerusi blog dan masalah-masalah yang menjadi kekangan kepada kelancaran proses ini. Berdasarkan kepada beberapa kajian lepas, banyak faktor yang dapat membantu murid-murid dalam menunjukkan pencapaian yang positif (Scott et al., 2016) menerusi blog iaitu antaranya pengintegrasian proses kemahiran berfikir (Cooper, 2012). Implementasi blog dalam pengajaran dan pembelajaran masa kini sedikit sebanyak dapat menyediakan satu ruang untuk 
melaksanakan proses pembelajaran yang efektif dan teratur (Frye et al., 2010). Terdapat beberapa faktor perlu dipertimbangkan untuk memastikan penggunaan blog dalam pengajaran dan pembelajaran mengikut kualiti yang dikehendaki (Hargrove, 2013). Antaranya ialah Strategi (Wang et al., 2017), Teori (Ciampa \& Gallagher, 2015), Gaya pengajaran (Mohamed et al., 2013) dan Model pengajaran dan pembelajaran (Loving et al., 2007) yang sesuai untuk meningkatkan kemahiran belajar (Jackling et al., 2015), pencapaian (Villardón-Gallego, 2016) dan motivasi (Morgan, 2015) murid-murid menerusi blog pendidikan.

Apakah alasan yang wajar dan sesuai jika blog diaplikasikan dalam bidang Pendidikan? Adakah penggunaan blog dalam bidang pendidikan mempunyai tarikan yang tersendiri dalam memacu kecemerlangan pendidikan untuk sejagat? Ini merupakan beberapa persoalan yang difikirkan oleh golongan pendidik dalam mengintegrasikan blog dalam pengajaran dan pembelajaran. Aktiviti-aktiviti yang terkandung dalam blog pendidikan hendaklah sepenuhnya diekplotasikan bagi memastikan semua pendekatan pengajaran yang digunakan oleh guru-guru akan mendapat reaksi yang positif daripada murid-muridnya dalam proses meningkatkan pencapaian mereka (Regina D. Rosyer, 2010).

Persekitaran pembelajaran blog inkuiri ini adalah berdasarkan kepada model Bybee et al. (2006). Jadual 1, menghuraikan keterangan fasa 5E mengikut Bybee et al. (2006):

Jadual 1 : Penerangan fasa 5E

\begin{tabular}{ll}
\hline Fasa 5E & Keterangan \\
\hline Penglibatan & Fasa yang melibatkan penglibatan diri. Fasa ini merupakan fasa untuk \\
(Engage $)$ & menarik minat, perhatian serta peningkatan motivasi murid untuk kekal \\
& aktif. Peningkatan semangat inkuiri dalam diri murid-murid juga berlaku \\
& dalam fasa ini. Proses yang berlangsung dalam fasa ini merupakan fasa \\
& yang berlangsung diawal proses pembelajaran sama ada di dalam atau di \\
& luar bilik darjah. Pelbagai kaedah boleh dilaksanakan difasa ini antaranya \\
& ialah penerangan, pemberian latih tubi, video montaj dan lain-lain \\
& sumber yang boleh digunakan untuk mencapai tahap fasa penglibatan.
\end{tabular}

Penerokaan Fasa ini tersedia untuk murid-murid mengeksplorasi dan memberi ruang (Explore) kepada mereka untuk melaksanakan perbincangan dalam kumpulan serta penglibatan aktif murid-murid dalam setiap bahagian aktiviti pembelajaran. Fasa ini dapat membantu murid-murid menguasai konsep, memperbaiki kefahaman tentang konsep pembelajaran, menguasai proses pemikiran serta kemahiran. Murid juga perlu menggunakan peluang di fasa ini untuk meningkatkan minat murid, semangat inkuiri merangsang untuk bertanya soalan.

Penerangan Fasa ini memerlukan fokus daripada murid-murid untuk aspek-aspek (Explain) yang tertentu untuk meningkatkan proses kefahaman di fasa dua dan tiga. Murid-murid diberi peluang untuk mempersembahkan pemahaman mereka secara kontekstual, kemahiran, proses, serta kelakuan. Di fasa ini, guru memainkan peranan yang penting kerana guru akan memperkenalkan dan memberi penerangan mengenai proses, kemahiran dan konsep pembelajaran.

Penghuraian Fasa ini merupakan satu untuk murid-murid mengalikasikan penguasaan (Elaborate) dan pemahaman mereka untuk aktiviti pembelajaran serta mengukuhkan lagi kefahaman dan pengetahuan mereka. Fasa ini membenarkan muridmurid untuk memperbaiki kekeliruan dan ketidakfahaman mereka dan mendapat ilmu yang baru untuk difahami dengan lebih mendalam lagi.

Penilaian Fasa ini merupakan fasa menilai pengetahuan, pemahaman, proses dan (Evaluate) konsep yang ditelah dipelajari selaras dengan objektif pembelajaran yang 


telah dirancang. Pelbagai kaedah penilaian boleh dilaksanakan iaitu soal
jawab, soalan latihan, kuiz dan sebagainya. Murid-murid juga boleh
membuat pembentangan hasil aktiviti secara nyata atau maya selepas
selesai kesemua keempat-empat fasa yang tersedia sebelum fasa
penilaian berlangsung.

*Sumber: Bybee et al. (2006)

Manakala untuk pencapaian murid sebelum dan selepas penggunaan blog reflektif melalui kaedah inkuiri mengaplikasikan model taksonomi oleh Krathwohl (2002). Motivasi murid-murid sebelum dan selepas pula menggunakan soal selidik Instructional Material Motivation Survey (IMMS) oleh Keller (2010). Rajah 1 menunjukkan kerangka teori untuk tujuan keseluruhan kajian ini.

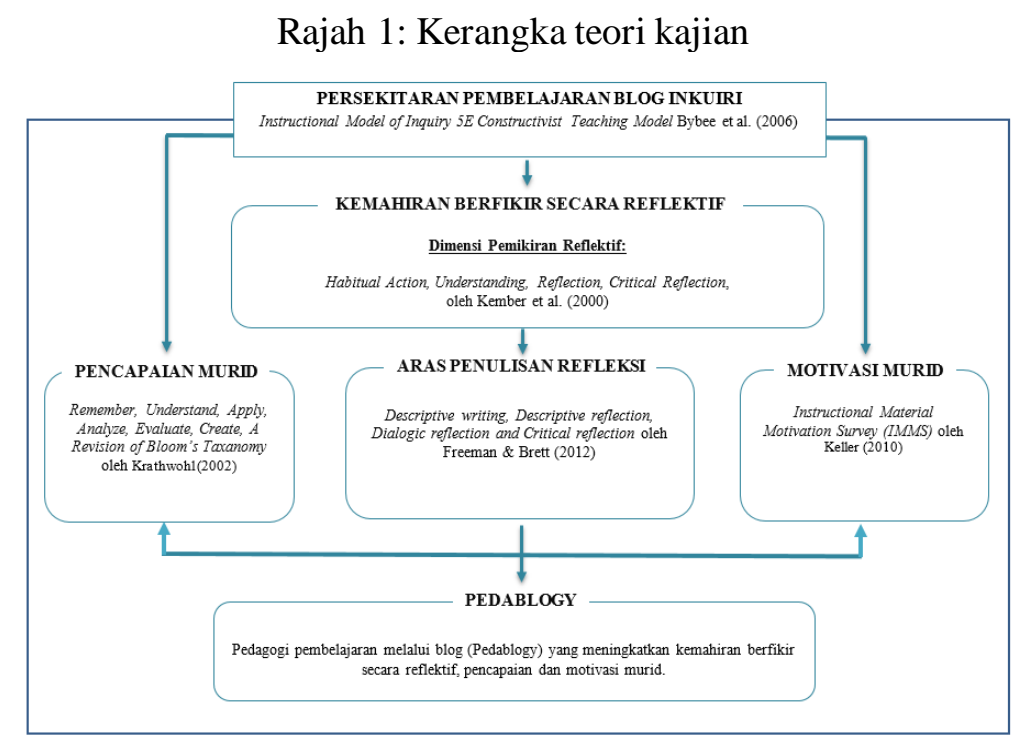

\section{Tujuan Kajian}

Kajian ini bertujuan untuk menentukan kesan sama ada pembelajaran secara inkuiri menerusi blog (Pedablogy) dapat meningkatkan pencapaian dan motivasi.

\section{Objektif Kajian}

Objektif kajian ini ialah:

i. Membina aktiviti pembelajaran autentik reflektif yang sesuai menerusi blog bagi topik Teorem Pitagoras Matematik Tingkatan Empat.

ii. Menganalisis kesan penggunaan blog pembelajaran secara reflektif melalui kaedah inkuiri terhadap pencapaian murid.

iii. Menganalisis kesan penggunaan blog pembelajaran secara reflektif melalui kaedah inkuiri terhadap motivasi murid.

\section{Persoalan Kajian}

Persoalan kajian ini ialah:

i. Apakah aktiviti pembelajaran autentik reflektif yang sesuai menerusi blog bagi topik Teorem Pitagoras Matematik Tingkatan Empat?

ii. Apakah kesan penggunaan blog pembelajaran secara reflektif melalui kaedah inkuiri terhadap pencapaian murid?

iii. Apakah kesan penggunaan blog pembelajaran secara reflektif melalui kaedah inkuiri terhadap motivasi murid? 


\section{Hipotesis Kajian}

Hipotesis kajian ini ialah:

$\mathrm{H}_{01}$ : Tidak terdapat perbezaan yang signifikan antara pencapaian murid sebelum dan selepas penggunaan blog secara reflektif melalui kaedah inkuiri.

$\mathrm{H}_{02}$ : Tidak terdapat perbezaan yang signifikan antara motivasi murid sebelum dan selepas penggunaan blog secara reflektif melalui kaedah inkuiri.

\section{Metod Kajian}

Reka bentuk kajian ini ialah kajian eksperimen jenis pra-pasca satu kumpulan. Menerusi reka bentuk kajian ini, terdapat satu kumpulan kajian yang akan diuji iaitu kumpulan rawatan (KR). Kumpulan ini akan menjalani ujian pra untuk membuktikan sama ada kebolehan atau keupayaan kedua kumpulan adalah sama atau berbeza. Selepas melalui proses kajian, kumpulan ini akan menjalani ujian pasca. Ujian pasca digunakan bagi mengenalpasti perbezaan keupayaan atau kebolehan kumpulan.

Instrumen soal selidik Instructional Materials Motivation Survey (IMMS) dan Dimensi Pemikiran reflektif telah diuji kebolehpercayaannya dengan ujian kebolehpercayaan test-retest dan ujian konsistensi dalaman. Seramai 20 orang responden digunakan untuk menjawab soal selidik ini. Soal selidik ini telah melalui satu proses penterjemahan dari Bahasa Inggeris kepada Bahasa Melayu. Pekali Cronbach Alpha telah digunakan untuk mentaksir kebolehpercayaan kedua-dua instrumen. Hasil dapatan ujian kebolehpercayaan bagi nilai cronbach alpha untuk soal selidik IMMS ialah 0.981 manakala soal selidik Dimensi Pemikiran reflektif pula ialah 0.741. Kedua-dua instrumen tersebut telah melebihi nilai 0.7. Ini menunjukkan instrumen tersebut dianggap sah digunakan untuk menilai pengetahuan atau kemahiran manakala nilai melebihi 0.6 instrumen tersebut dianggap boleh dipercayai (Landis, J., \& Koch, 1977).

Sampel kajian yang terlibat dalam kajian ini ialah sejumlah 30 orang pelajar Tingkatan empat di sebuah sekolah di selatan tanahair. Pemilihan sampel adalah menggunakan kaedah rawak kluster manakala pemilihan sekolah adalah secara bertujuan.

Ujian t sampel berpasangan (paired-samples $t$-test) dijalankan dengan menggunakan perisian SPSS dengan nilai $\alpha=0.05$, bagi mengkaji sama ada penggunaan blog secara reflektif melalui kaedah inkuiri memberikan kesan yang signifikan kepada pencapaian murid. Ujian t sampel berpasangan ini digunakan untuk membandingkan dua pemboleh ubah iaitu skor ujian pra dan ujian pasca. Wilcoxon signed rank test dijalankan dengan menggunakan perisian SPSS dengan nilai $\alpha=0.05$, bagi mengkaji sama ada penggunaan blog secara reflektif melalui kaedah inkuiri memberikan kesan yang signifikan kepada motivasi murid. Wilcoxon signed rank test ini digunakan untuk membandingkan dua pemboleh ubah iaitu skor motivasi pra dan motivasi pasca.

\section{Hasil Kajian}

\section{Aktiviti Pembelajaran Autentik ReflektifYang Sesuai Menerusi Blog Bagi Topik Teorem Pitagoras Matematik Tingkatan 4}

Penentuan strategi pembelajaran yang tepat dalam kajian ini akan memastikan setiap komponen yang direka boleh berfungsi dengan baik dan selari dengan objektif kajian ini. Kajian ini mengaplikasikan kaedah pembelajaran secara inkuiri. Model pembelajaran inkuiri 5E yang dikenali juga sebagai $5 E$ Instructional Model yang dipelopori oleh sekumpulan pengkaji dari Biological Sciences Curriculum Study (BSCS) (Bybee et al., 2006) telah dipilih. Model ini dipilih kerana ianya lebih praktikal, teratur dan sesuai untuk meningkatkan tahap pembelajaran pelajar. Jadual 2 merupakan ringkasan aktiviti yang ada dalam blog guru untuk dilaksanakan oleh murid-murid dalam blog mereka. 
Jadual 2: Aktiviti inkuiri di blog guru

\begin{tabular}{|c|c|c|c|c|}
\hline Bil & Aktiviti & Objektif & $\begin{array}{c}\text { Hasil } \\
\text { Pembelajaran }\end{array}$ & Isi Kandungan \\
\hline 1. & $\begin{array}{l}\text { Petak Batu Bata } \\
\text { ( Aktiviti Petak } \\
\text { Kuasa Dua) }\end{array}$ & $\begin{array}{l}\text { O1: } \\
\text { Memahami dan } \\
\text { menggunakan } \\
\text { akas Teorem } \\
\text { Pythagoras. }\end{array}$ & $\begin{array}{l}\text { HP1: } \\
\text { Menentukan } \\
\text { suatu segitiga } \\
\text { adalah suatu } \\
\text { segitiga bersudut } \\
\text { tegak dan } \\
\text { memberi } \\
\text { justifikasi } \\
\text { berdasarkan akas } \\
\text { Teorem } \\
\text { Pythagoras }\end{array}$ & 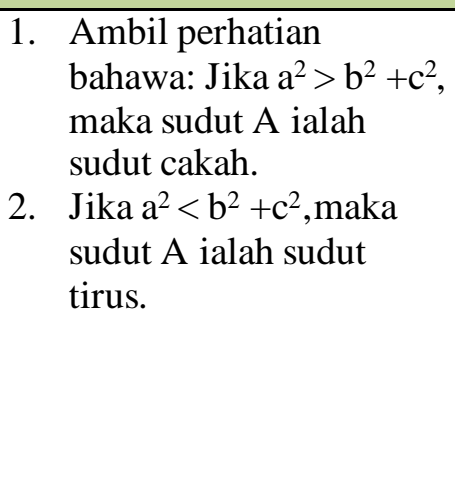 \\
\hline 2. & $\begin{array}{l}\text { Hai Arkitek Ku! } \\
\text { (Bina rumah } \\
\text { berdasarkan sudut } \\
\text { tegak tiang rumah) }\end{array}$ & & $\begin{array}{l}\text { HP2: } \\
\text { Menentukan } \\
\text { salah satu sisi } \\
\text { segiempat tepat } \\
\text { adalah } \\
\text { bersudut tegak } \\
\text { dan memberi } \\
\text { justifikasi } \\
\text { berdasarkan akas } \\
\text { Teorem } \\
\text { Pythagoras }\end{array}$ & \\
\hline 3. & $\begin{array}{l}\text { Jalan Terjauh? } \\
\text { (Mencari sisi kedua } \\
\text { terpanjang selain } \\
\text { hipotenus sama ada } \\
\text { sisi bersebelahan } \\
\text { atau sisi } \\
\text { bersetentangan) }\end{array}$ & $\begin{array}{l}\text { O2: } \\
\text { Mengenal pasti } \\
\text { hipotenus } \\
\text { segitiga bersudut } \\
\text { tegak } \\
\text { yang dilukis } \\
\text { dalam perlbagai } \\
\text { orientasi. }\end{array}$ & $\begin{array}{l}\text { HP3: } \\
\text { Mengenal pasti } \\
\text { hipotenus } \\
\text { segitiga bersudut } \\
\text { tegak. }\end{array}$ & ${ }^{b}$ \\
\hline 4. & $\begin{array}{l}\text { Masa Itu Emas! } \\
\text { (Memilih sisi } \\
\text { terpendek atau } \\
\text { jalan terpendek } \\
\text { untuk } \\
\text { mengurangkan } \\
\text { masa perjalanan) }\end{array}$ & $\begin{array}{l}\text { O3: } \\
\text { Menentukan } \\
\text { panjang sisi } \\
\text { segitiga bersudut } \\
\text { tegak } \\
\text { menggunakan } \\
\text { Teorem } \\
\text { Pythagoras }\end{array}$ & $\begin{array}{l}\text { Mengenal pasti } \\
\text { sisi selain } \\
\text { hipotenus segitiga } \\
\text { bersudut } \\
\text { tegak. }\end{array}$ & $\begin{array}{l}\text { 1. Tegaskan bahawa } \\
\mathrm{a}^{2}=\mathrm{b}^{2}+\mathrm{c}^{2} \text { ialah Teorem } \\
\text { Pythagoras. Mulakan } \\
\text { dengan tiga rangkap } \\
\text { Pythagoras. } \\
\text { 2. Contoh: }(3,4,5), \\
(5,12,13) \\
\text { 3. Termasuk bentuk } \\
\text { geometri bergabung. }\end{array}$ \\
\hline 5. & $\begin{array}{l}\text { Dinamika Teorem } \\
\text { (sisi hipotenus } \\
\text { kuasa dua } \\
\text { berkadaran dengan } \\
\text { hasil tambah sisi } \\
\text { bersebelahan kuasa } \\
\text { dua tambah sisi }\end{array}$ & & $\begin{array}{l}\text { HP4: } \\
\text { Menentukan } \\
\text { hubungan antara } \\
\text { panjang sisi } \\
\text { segitiga bersudut } \\
\text { tegak. } \\
\text { Mengenal pasti } \\
\text { sisi bertentangan }\end{array}$ & $\begin{array}{l}\text { 1. Membuat perkaitan } \\
\text { dengan konsep } \\
\text { perkadaran. } \\
\text { 2. Menentusahkan kesan } \\
\text { perubahan } \\
\text { menggunakan nisbah } \\
\text { sisi segit tiga bersudut } \\
\text { tegak. Sudut } 0^{0} \text { dan } 90^{\circ}\end{array}$ \\
\hline
\end{tabular}




\begin{tabular}{|c|c|c|c|c|}
\hline & $\begin{array}{l}\text { bersetentangan } \\
\text { kuasa dua) }\end{array}$ & & $\begin{array}{l}\text { dan sisi } \\
\text { bersebelahan } \\
\text { berdasarkan suatu } \\
\text { sudut tirus dalam } \\
\text { segi tiga bersudut } \\
\text { tegak. }\end{array}$ & $\begin{array}{l}\text { darjah perlu dilibatkan. } \\
\text { 3. Meneroka hubungan } \\
\tan \theta=\frac{\sin \theta}{\operatorname{kos} \theta}\end{array}$ \\
\hline 6. & $\begin{array}{l}\text { Saya Tak Hafal? } \\
\text { ( Aktiviti meneroka } \\
\text { nilai dan maksud } \\
\text { "Saya Tak Hafal, } \\
\text { Kalau Saya Hafal, } \\
\text { Tentu Tak Susah") }\end{array}$ & $\begin{array}{l}\text { O4: } \\
\text { Menggunakan } \\
\text { nilai Sinus, } \\
\text { Kosinus, dan } \\
\text { Tangen bagi } \\
\text { Sudut Tirus } \\
\text { dalam } \\
\text { segitiga bersudut } \\
\text { tegak. }\end{array}$ & $\begin{array}{l}\text { HP5: } \\
\text { Membuat dan } \\
\text { menentusahkan } \\
\text { konjektur tentang } \\
\text { hubungan } \\
\text { antara sudut tirus } \\
\text { dan nisbah } \\
\text { sisi segi tiga } \\
\text { bersudut tegak } \\
\text { dan seterusnya } \\
\text { mentakrifkan } \\
\text { sinus, kosinus } \\
\text { dan tangen. } \\
\text { Menentukan nilai } \\
\text { sinus, kosinus } \\
\text { dan tangen suatu } \\
\text { sudut tirus. }\end{array}$ & 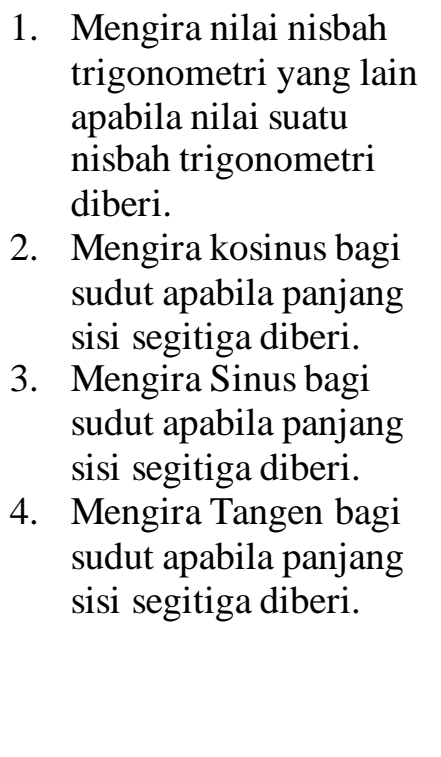 \\
\hline 7. & $\begin{array}{l}\text { Dongak Ke Langit? } \\
\text { (Aktiviti mencari } \\
\text { nilai sudut dongak) }\end{array}$ & $\begin{array}{l}\text { O5: } \\
\text { Menggunakan } \\
\text { nilai tangen, } \\
\text { sinus dan } \\
\text { kosinus untuk } \\
\text { menyelesaikan } \\
\text { masalah sudut } \\
\text { dongak dan } \\
\text { sudut tunduk. }\end{array}$ & $\begin{array}{l}\text { HP6: } \\
\text { Menentukan saiz } \\
\text { sudut apabila } \\
\text { diberi nilai } \\
\text { tangen, sinus dan } \\
\text { kosinus. }\end{array}$ & 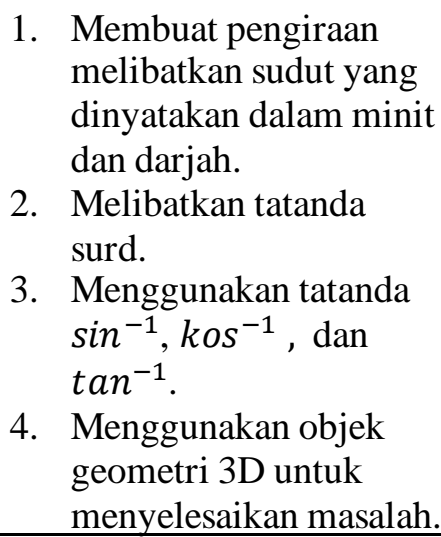 \\
\hline
\end{tabular}

Rajah 2 hingga 9 menunjukkan contoh paparan di blog guru untuk aktiviti penggunaan blog reflektif melalui kaedah inkuiri. Setiap aktiviti yang terkandung di dalam blog guru akan disusun seperti paparan di Rajah 2 hingga 9 mengikut tajuk dan objektif pembelajaran yang telah dirancang seperti di Jadual 1 . Aktiviti-aktiviti di blog guru telah disemak oleh pakar kandungan yang berkaitan. Selain itu, ilustrasi dan rekabentuk kandungan pembelajaran dibuat dalam bentuk bergambar dan berwarna sesuai dengan tujuan untuk menarik minat murid-murid menyiapkan tugasan yang diberi dengan lebih bermotivasi. Setiap aktiviti yang tersedia menerapkan beberapa elemen autentik agar murid-murid tidak terikat kepada perkongsian maklumat formal dan satu hala. Dengan ini, mereka dapat lebih bereksplorasi untuk menerangkan penyelesaian mereka dan mempersembahkannya dalam bentuk yang lebih kreatif dan bermakna. Sehubungan dengan itu, objektif kajian dapat dicapai dengan baik kerana isi kandungan pembelajaran sejajar dengan kaedah penyampaian yang baik dan berkesan untuk murid-murid. 


\section{Minggu 1:}

\section{PUBLISHED ON MaY 4, 2020 \\ ${ }^{0}$ Rate This

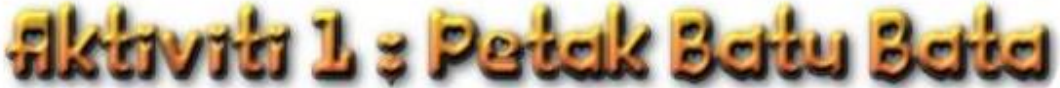

Faiz dan Hassan merupakan dua orang murid di sebuah sekolah menengah di sekitar Johor Bahru. Mereka berdua telah ditugaskan untuk membina pelan Taman Rekreasi yang mempunyai beberapa Kolam Ikan yang berbentuk segetiga bersudut tegak. Terdapat beberapa perkara yang perlu difikirkan oleh mereka sebelum pelan Taman Rekreasi ini dibuat. Jom ikuti perbincangan mereka dengan Pengetua sekolah.

Rajah 2: Paparan jalan cerita untuk fasa engage di blog guru

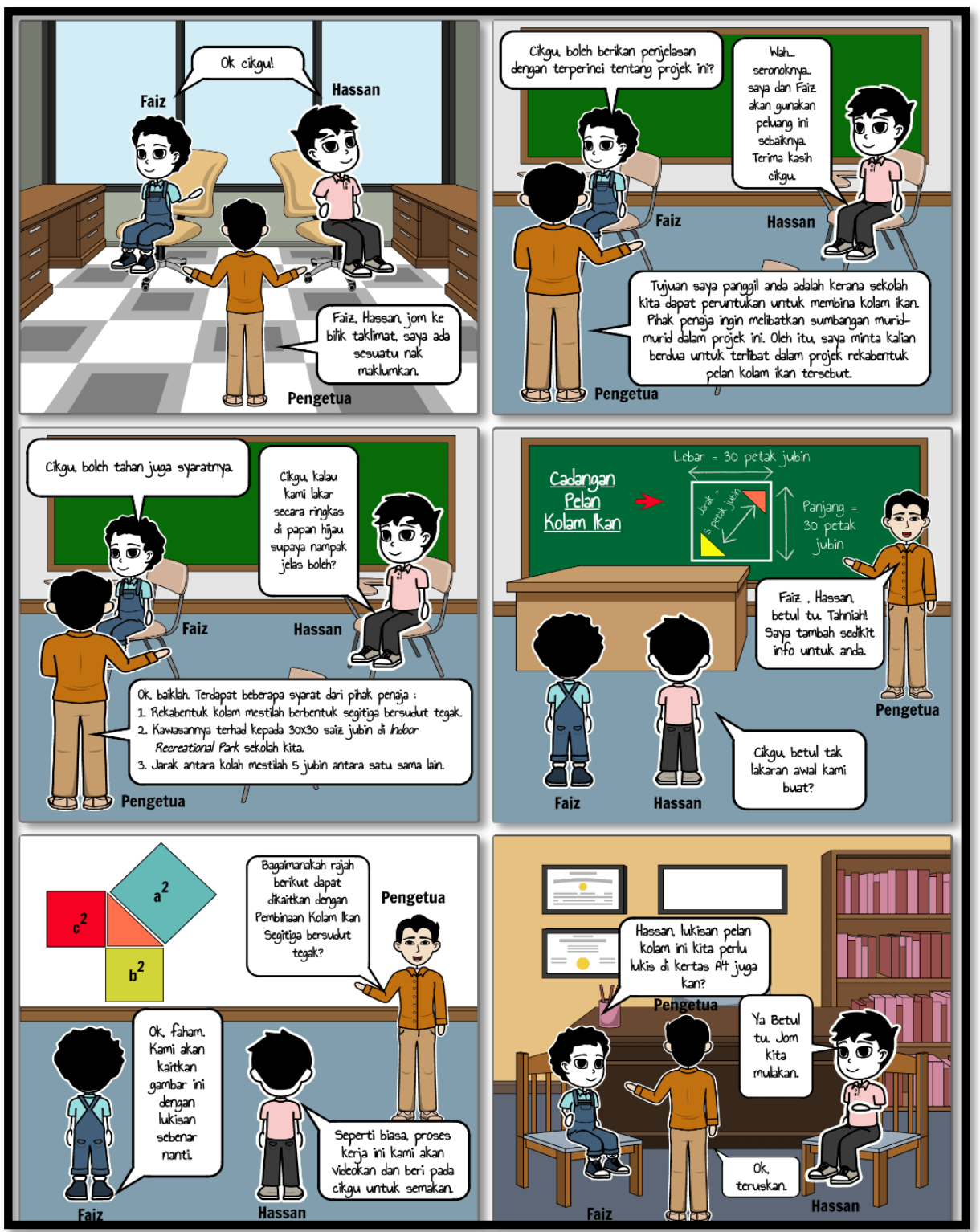


DOI: https://doi.org/10.47405/mjssh.v6i2.675

Rajah 3: Paparan visual untuk fasa engage di blog guru

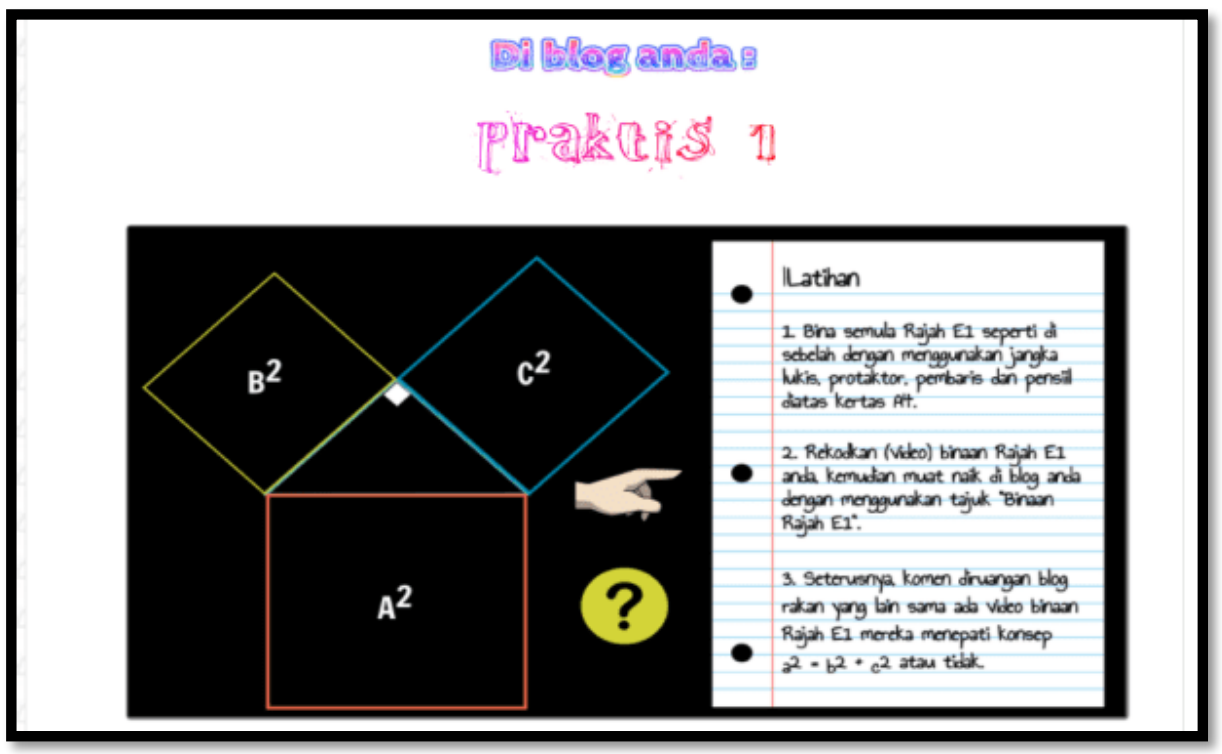

Rajah 4: Paparan praktis 1 untuk fasa explore di blog guru

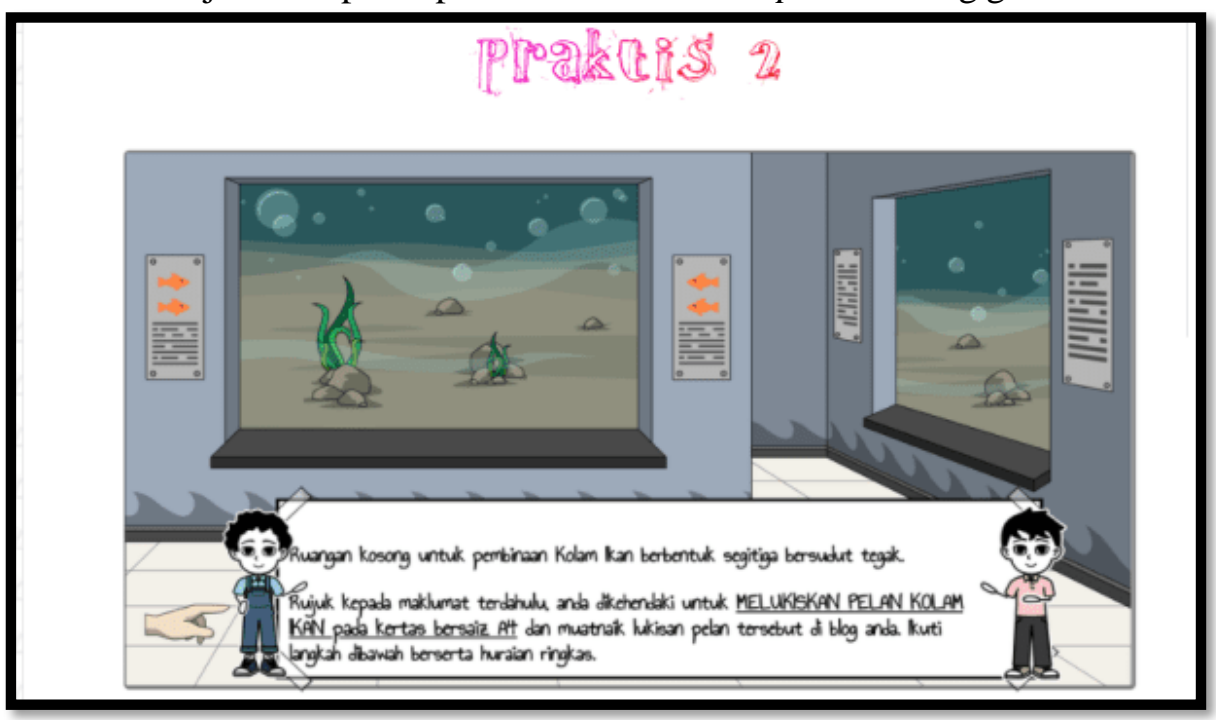

Rajah 5: Paparan praktis 2 untuk fasa explain di blog guru

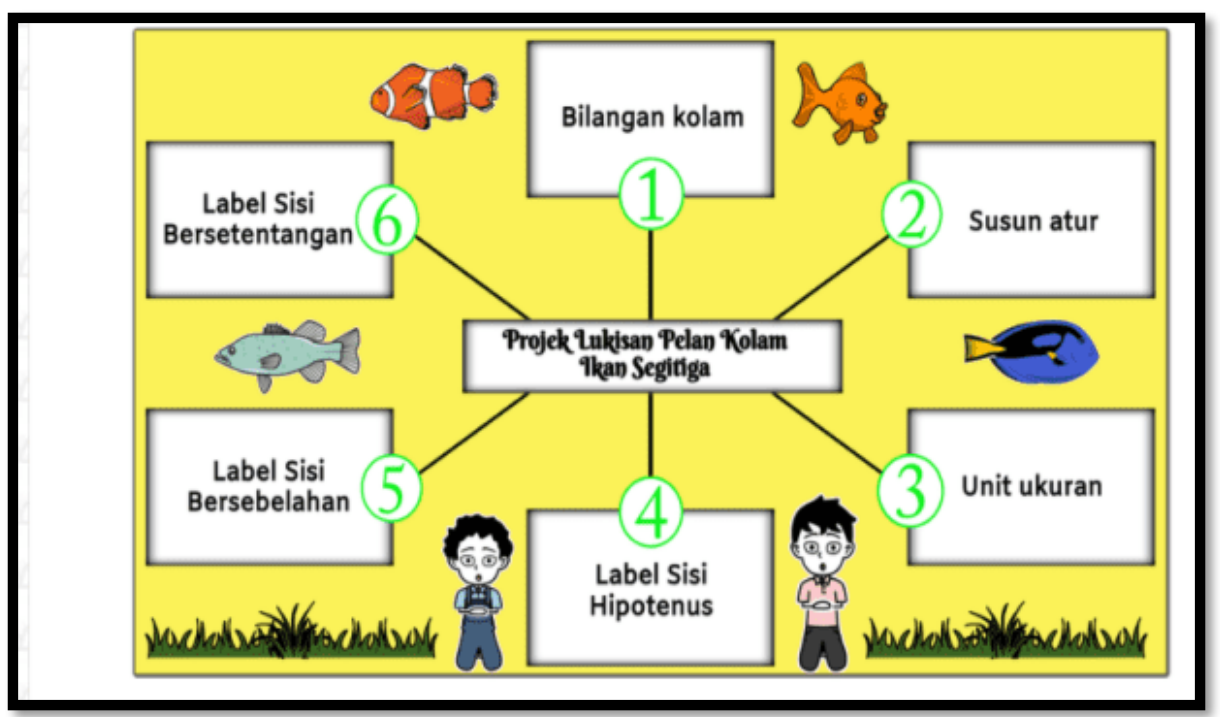


Rajah 6: Paparan visual praktis 2 untuk fasa explain di blog guru

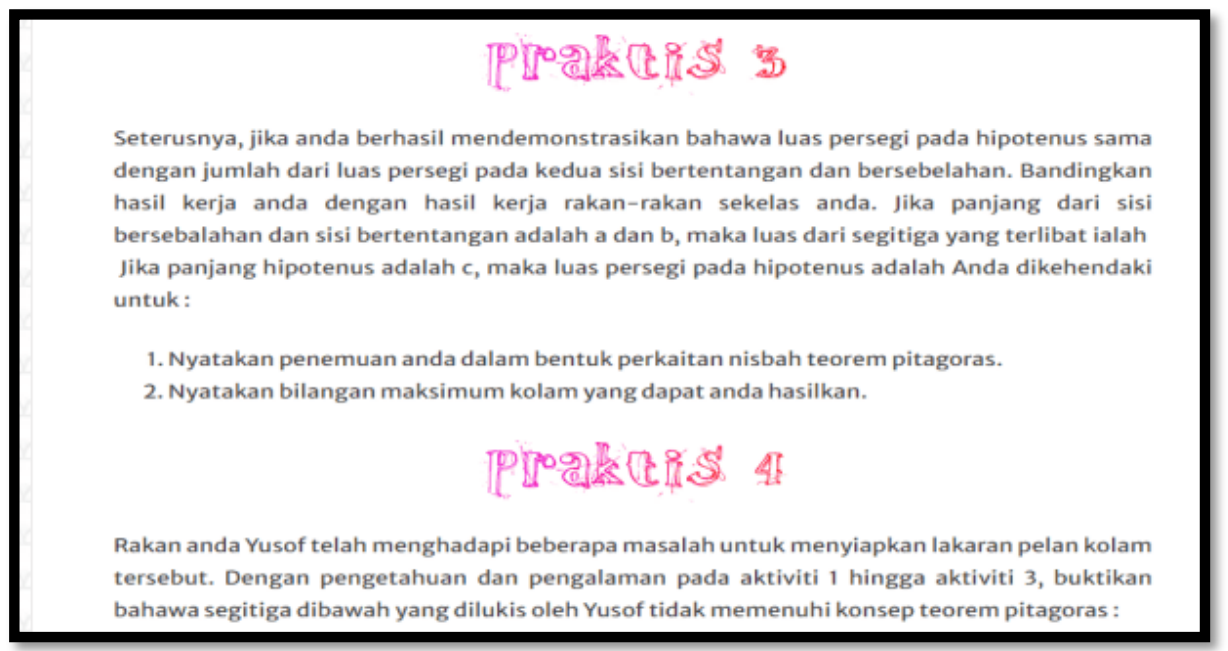

Rajah 7: Paparan praktis 3 untuk fasa elaborate di blog guru

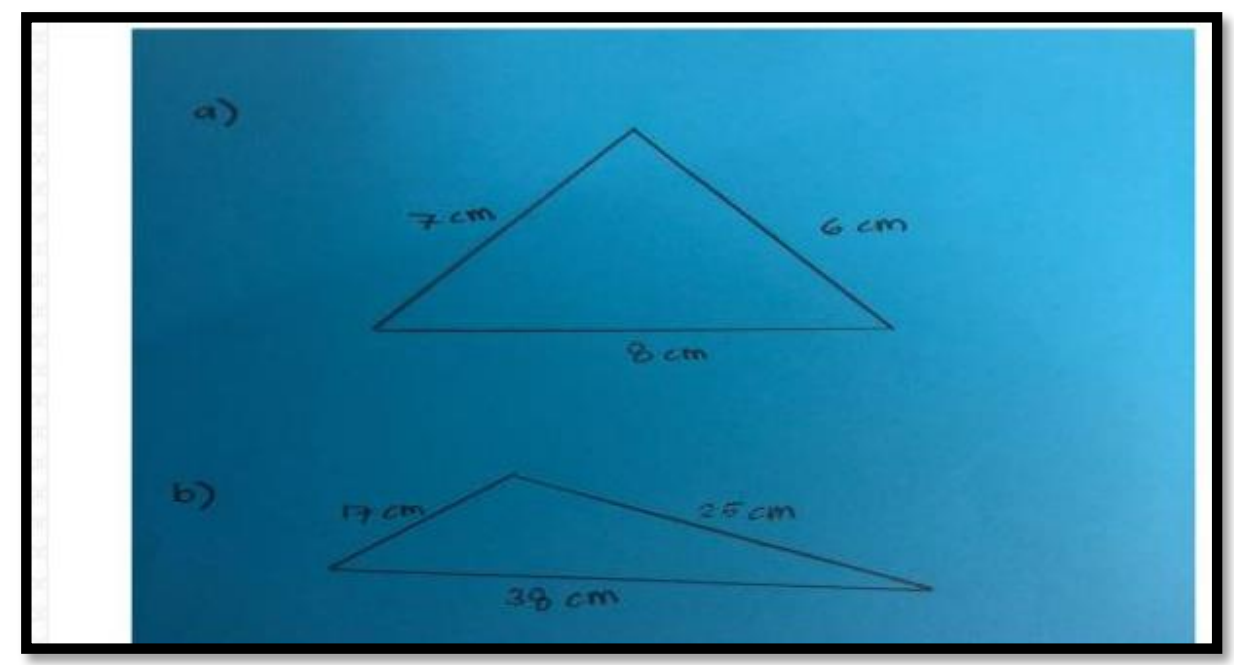

Rajah 8: Paparan praktis 4 untuk fasa evaluate di blog guru

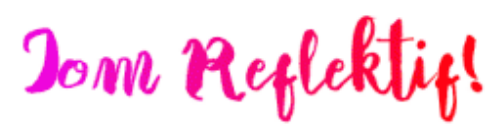

Sila klik link dibawah untuk mengetahui maklumat lanjut mengenai penulisan refleksi anda.

https://www.powtoon.com/embed/bE1FMtu77cx/

1. Sebahagian sumber imej, gambar, video, audio adalah ihsan daripada google dan tujuan digunakan untuk kepentingan pendidikan bukan komersial.

2. Imej komik adalah daripada https://www.storyboardthat.com/

3. Tulisan adalah daripada https://fontmeme.com/fonts/jamaistevie-font/

4. Video animasi adalah daripada https://www, powtoon.com/.

SHARE THIS:

(10) Press This Tweet

Customice tuattons

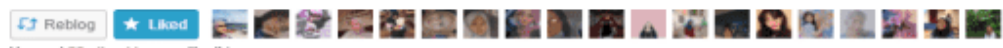

Rajah 9: Paparan jom reflektif untuk penulisan refleksi di blog guru 


\section{Kesan Penggunaan Blog Pembelajaran Secara ReflektifMelalui Kaedah Inkuiri dalam Pengajaran Dan Pembelajaran Terhadap Pencapaian Murid}

Berdasarkan Jadual 3, hipotesis nul telah ditolak kerana pencapaian murid dalam ujian pasca $(\mathrm{M}=86.17$, $S D=3.630)$ telah meningkat secara signifikan berbanding ujian pra $(\mathrm{M}=48.80, S D=5.088)$ dengan nilai $p=0.000(p<0.05)$. Maka keputusan ujian t sampel berpasangan menunjukkan terdapat perbezaan yang signifikan antara pencapaian murid sebelum dan selepas penggunaan blog reflektif melalui kaedah inkuiri. Memandangkan nilai min ujian pasca adalah lebih tinggi berbanding dengan nilai min ujian pra $\left(\mathrm{M}_{\text {beza }}=37.37\right)$, maka ia menunjukkan bahawa penggunaan blog reflektif melalui kaedah inkuiri telah meningkatkan tahap pencapaian murid.

Kesimpulannya, hasil ujian $\mathrm{t}$ sampel berpasangan menunjukkan bahawa penggunaan blog reflektif melalui kaedah inkuiri telah meningkatkan pencapaian murid. Bagi menentukan sama ada peningkatan dalam ujian pasca pencapaian adalah signifikan dan bukan disebabkan kebetulan, maka analisis statistik kuasa post hoc dan apriori telah dilaksanakan dengan menggunakan perisian $G$ *Power, versi 3.1.9.2. Berdasarkan kepada Jadual 4, didapati hasil analisis post hoc menunjukkan nilai kuasa bagi kesan saiz 6.354 adalah 1.00. Ia menunjukkan bahawa nilai tersebut adalah kesan saiz yang paling besar yang dicadangkan. Sekiranya ujian ini diulangi untuk beberapa kali, ia akan melaporkan keputusan yang sama akan diperolehi. Rajah 10 juga menunjukkan beberapa nilai parameter yang berbeza untuk menentukan kuasa kajian pos hoc. Seterusnya, analisis apriori menunjukkan bahawa 3 sampel adalah mencukupi bagi kesan saiz 6.354 (rujuk Jadual 5). Rajah 11 juga menunjukkan beberapa nilai parameter yang berbeza untuk menentukan kuasa kajian apriori. Oleh yang demikian, nilai sampel dalam kajian ini $(n=30)$ telah mencapai aras signifikan $(p<0.05)$ dan kuasa $(1-\beta=1.00)$ yang diperlukan.

Jadual 3: Keputusan ujian t sampel berpasangan bagi pencapaian murid

\begin{tabular}{ccccccccc}
\hline & \multicolumn{3}{c}{ Paired Differences } & & & Sig. \\
\cline { 2 - 5 } & Mean & $\begin{array}{c}\text { Std. } \\
\text { Deviation }\end{array}$ & $\begin{array}{c}\text { Std. } \\
\text { Error } \\
\text { Mean }\end{array}$ & & t & df & $\begin{array}{c}(\mathbf{2}- \\
\text { tailed) }\end{array}$ \\
\cline { 2 - 7 } ujian pasca - ujian pra & -37.367 & 5.881 & 1.074 & -34.802 & 29 & .000 \\
\hline
\end{tabular}

Jadual 4: Analisis statistik kuasa post hoc pencapaian

\begin{tabular}{cccccc}
\hline $\begin{array}{c}\text { Kuasa Capaian } \\
(\mathbf{1}-\boldsymbol{\beta})\end{array}$ & $\begin{array}{c}\text { Kesan Saiz } \\
\text { Capaian, } \\
\text { Cohen d }\end{array}$ & $\begin{array}{c}\text { Genting, } \\
\mathbf{t}\end{array}$ & Delta & $\begin{array}{c}\text { Sampel } \\
\text { Sebenar, } \\
\mathbf{n}\end{array}$ & $\begin{array}{c}\text { Darjah } \\
\text { Kebebasan, } \\
\text { df }\end{array}$ \\
\hline 1.00 & 6.354 & 2.045 & 34.801 & 30 & 29 \\
\hline
\end{tabular}

Jadual 5: Analisis statistik kuasa apriori pencapaian

\begin{tabular}{cccccc}
\hline $\begin{array}{c}\text { Kuasa Capaian } \\
(\mathbf{1}-\boldsymbol{\beta})\end{array}$ & $\begin{array}{c}\text { Kesan Saiz } \\
\text { Capaian, } \\
\text { Cohen d }\end{array}$ & $\begin{array}{c}\text { Genting, } \\
\mathbf{t}\end{array}$ & Delta & $\begin{array}{c}\text { Sampel } \\
\text { Minimum } \\
\text { Sampel, } \mathbf{n}\end{array}$ & $\begin{array}{c}\text { Darjah } \\
\text { Kebebasan, } \\
\text { df }\end{array}$ \\
\hline 0.99 & 6.354 & 4.303 & 11.005 & 3 & 2 \\
\hline
\end{tabular}




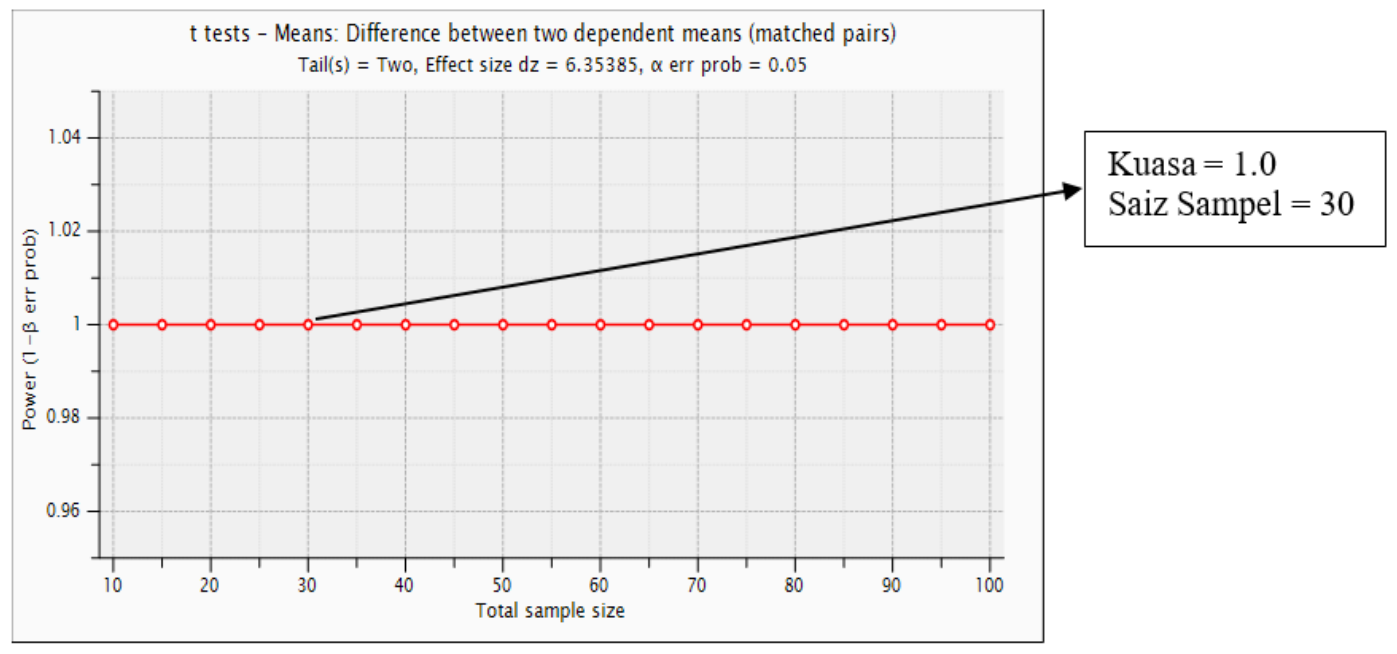

Rajah 10: Plot analisis statistik kuasa post hoc pencapaian

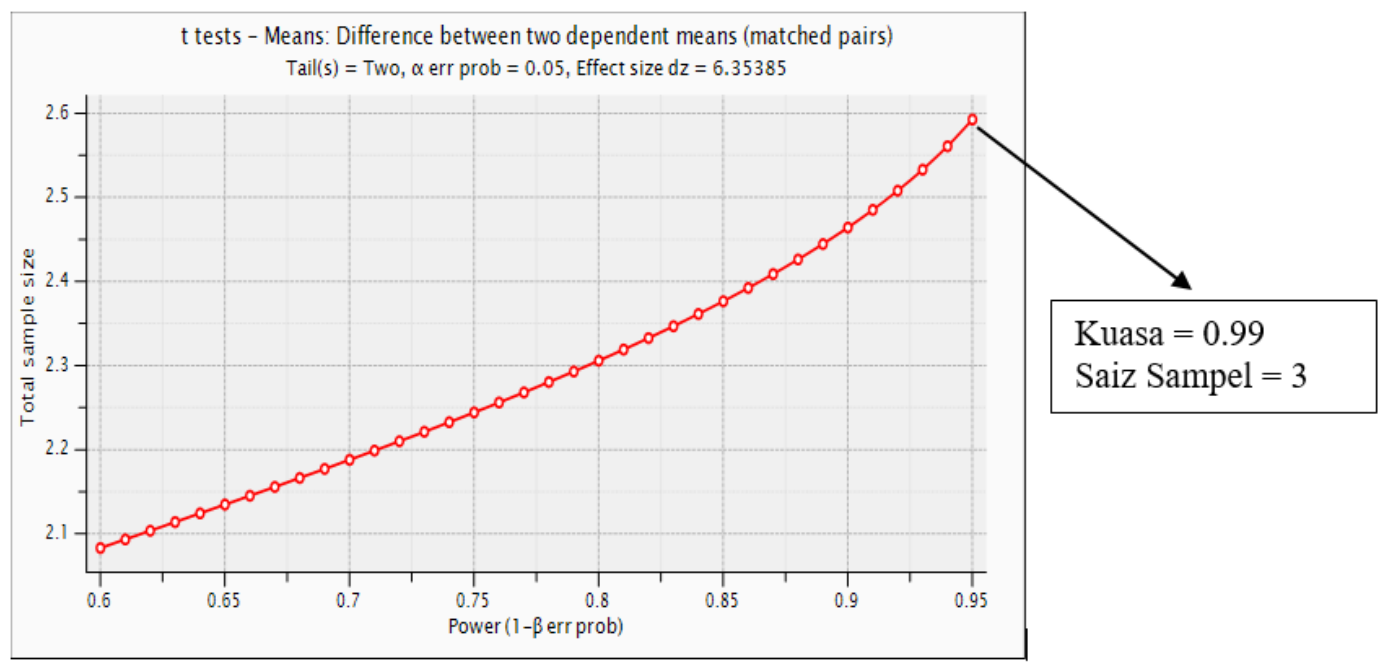

Rajah 11: Plot analisis statistik kuasa apriori pencapaian

\section{Kesan Penggunaan Blog Pembelajaran Secara ReflektifMelalui Kaedah Inkuiri Dalam Pengajaran Dan Pembelajaran Terhadap Motivasi Murid.}

Pelaporan ini dibuat dalam bentuk peratusan (\%), purata (Mean) dan nilai sisihan piawai (SD). Jadual 6 menunjukkan pelaporan pra dan pasca keputusan motivasi murid-murid ini bagi keempat-empat tahap motivasi yang diukur.

Jadual 6: Tahap pra dan pasca motivasi murid-murid

\begin{tabular}{clcccc}
\hline No. & Tahap Motivasi & Mean_Pra & SD_Pra & Mean_Pasca & SD_Pasca \\
\hline 1 & Perhatian (Attention) & 2.77 & 0.28 & 4.42 & 0.50 \\
2. & Relevan (Relevance) & 2.73 & 0.32 & 4.40 & 0.62 \\
3. & Keyakinan (Confidence) & 2.74 & 0.25 & 4.28 & 0.62 \\
4. & Kepuasan (Satisfaction) & 2.88 & 0.31 & 3.76 & 0.37 \\
& PURATA_IMMS & 2.77 & 0.24 & 4.30 & 0.51 \\
\hline
\end{tabular}

Jadual 6 menunjukkan perbezaan tahap pra dan pasca motivasi murid-murid sebelum dan selepas menggunakan blog reflektif melalui kaedah inkuiri. Secara keseluruhannya, pelaporan keputusan 
motivasi murid-murid menunjukkan terdapat peningkatan motivasi yang tinggi selepas penggunaan blog reflektif melalui kaedah inkuiri. Keputusan pelaporan menunjukkan nilai purata pasca motivasi muridmurid ialah 4.30 dengan nilai sisihan piawainya 0.51 berbanding sebelum penggunaan blog reflektif melalui kaedah inkuiri iaitu 2.77 dengan nilai sisihan piawainya 0.24 . Hasil keputusan ini menunjukkan bahawa tahap motivasi murid-murid meningkat selepas penggunaan blog secara reflektif melalui kaedah inkuiri.

Seterusnya, Wilcoxon signed rank test dijalankan dengan menggunakan perisian SPSS dengan nilai $\alpha=$ 0.05, bagi mengkaji sama ada penggunaan blog secara reflektif melalui kaedah inkuiri memberikan kesan yang signifikan kepada motivasi murid. Ujian ini digunakan sebagai alternatif dari ujian sampel $t$ berpasangan kerana data tidak tertabur secara normal berdasarkan analisis Shapiro. Wilcoxon signed rank test juga digunakan untuk mengetahui adanya perbezaan yang signifikan terhadap dua sampel yang saling berpasangan. Saiz sampel kajian ini ialah $n=30$.

Seterusnya, berdasarkan Jadual 7 dan Jadual 8, hipotesis nul telah ditolak kerana pasca motivasi (IMMS pasca) murid ( $\mathrm{M}=4.27, S D=0.513)$ telah meningkat secara signifikan berbanding pra motivasi (IMMS pra) murid $(\mathrm{M}=2.77, S D=0.244)$ dengan nilai $p=0.000(p<0.05)$. Maka keputusan Wilcoxon signed rank test menunjukkan terdapat perbezaan yang signifikan antara keseluruhan tahap motivasi murid sebelum dan selepas penggunaan blog reflektif melalui kaedah inkuiri. Memandangkan nilai min pasca motivasi murid adalah lebih tinggi berbanding dengan nilai min pra motivasi murid $\left(\mathrm{M}_{\text {beza }}=1.5\right)$, maka ia menunjukkan bahawa penggunaan blog reflektif melalui kaedah inkuiri telah meningkatkan keseluruhan tahap motivasi murid. Kesimpulannya, hasil ujian Wilcoxon signed rank test menunjukkan bahawa penggunaan blog reflektif melalui kaedah inkuiri telah meningkatkan motivasi murid.

Jadual 7: Keputusan Wilcoxon signed rank test

\begin{tabular}{|c|c|c|c|c|}
\hline \multicolumn{5}{|c|}{ Ranks } \\
\hline & & V & $\begin{array}{l}\text { Mean } \\
\text { Rank }\end{array}$ & Sum of Ranks \\
\hline \multirow{4}{*}{$\begin{array}{l}\text { IMMSPasca - } \\
\text { IMMSPra }\end{array}$} & Negative Ranks & $1^{\mathrm{m}}$ & 3.00 & 3.00 \\
\hline & Positive Ranks & $29^{n}$ & 15.93 & 462.00 \\
\hline & Ties & $0^{\circ}$ & & \\
\hline & Total & 30 & & \\
\hline
\end{tabular}

Jadual 8: Statistik Wilcoxon signed rank test

\begin{tabular}{lrr}
\hline \multicolumn{3}{c}{ Test Statistics $^{\text {a }}$} \\
& IMMSPasca - IMMSPra \\
\hline Z & $-4.722^{\mathrm{b}}$ \\
Asymp. Sig. (2-tailed) & .000 \\
\hline
\end{tabular}

Bagi menentukan sama ada peningkatan dalam pasca motivasi adalah signifikan dan bukan disebabkan kebetulan, maka analisis statistic kuasa post hoc dan apriori telah dilaksanakan dengan menggunakan perisian $G^{*}$ Power, versi 3.1.9.2. Berdasarkan kepada Jadual 9, didapati hasil analisis post hoc menunjukkan nilai kuasa bagi kesan saiz 3.375 adalah 1.00. Ia menunjukkan bahawa nilai tersebut adalah kesan saiz yang paling besar yang dicadangkan. Sekiranya ujian ini diulangi untuk beberapa kali, ia akan melaporkan keputusan yang sama akan diperolehi. Rajah 12 juga menunjukkan beberapa nilai parameter yang berbeza untuk menentukan kuasa kajian. Seterusnya, analisis apriori menunjukkan bahawa 5 sampel adalah mencukupi bagi kesan saiz 3.375 (rujuk Jadual 10). Rajah 13 juga menunjukkan beberapa nilai parameter yang berbeza untuk menentukan kuasa kajian. Oleh yang demikian, nilai sampel dalam kajian ini $(n=30)$ telah mencapai aras signifikan $(p<0.05)$ dan kuasa $(1-\beta=1.00)$ yang diperlukan. 
Jadual 9: Analisis statistik kuasa post hoc motivasi

\begin{tabular}{cccccc}
\hline $\begin{array}{c}\text { Kuasa Capaian } \\
(\mathbf{1}-\boldsymbol{\beta})\end{array}$ & $\begin{array}{c}\text { Kesan Saiz } \\
\text { Capaian, } \\
\text { Cohen d }\end{array}$ & $\begin{array}{c}\text { Genting, } \\
\mathbf{t}\end{array}$ & Delta & $\begin{array}{c}\text { Sampel } \\
\text { Sebenar, } \\
\mathbf{n}\end{array}$ & $\begin{array}{c}\text { Darjah } \\
\text { Kebebasan } \\
\text { df }\end{array}$ \\
\hline 1.00 & 3.375 & 2.050 & 18.064 & 30 & 27.648 \\
\hline
\end{tabular}

Jadual 10: Analisis statistik kuasa apriori motivasi

\begin{tabular}{cccccc}
\hline $\begin{array}{c}\text { Kuasa Capaian } \\
(\mathbf{1}-\boldsymbol{\beta})\end{array}$ & $\begin{array}{c}\text { Kesan Saiz } \\
\text { Capaian, } \\
\text { Cohen d }\end{array}$ & $\begin{array}{c}\text { Genting, } \\
\mathbf{t}\end{array}$ & Delta & $\begin{array}{c}\text { Sampel } \\
\text { Minimu } \\
\mathbf{m , n},\end{array}$ & $\begin{array}{c}\text { Darjah } \\
\text { Kebebasan } \\
\text { df }\end{array}$ \\
\hline 0.99 & 3.375 & 2.843 & 7.375 & 5 & 3.775 \\
\hline
\end{tabular}

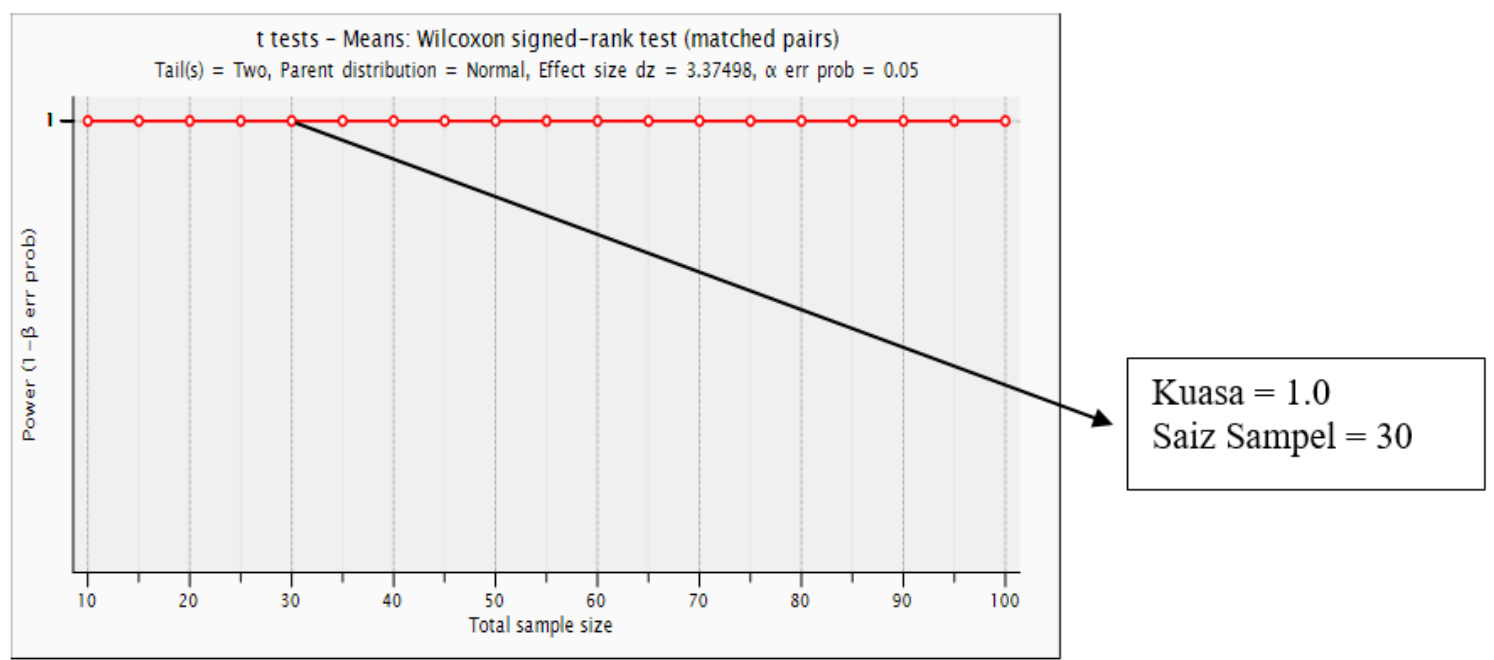

Rajah 12: Plot analisis statistik kuasa post hoc motivasi

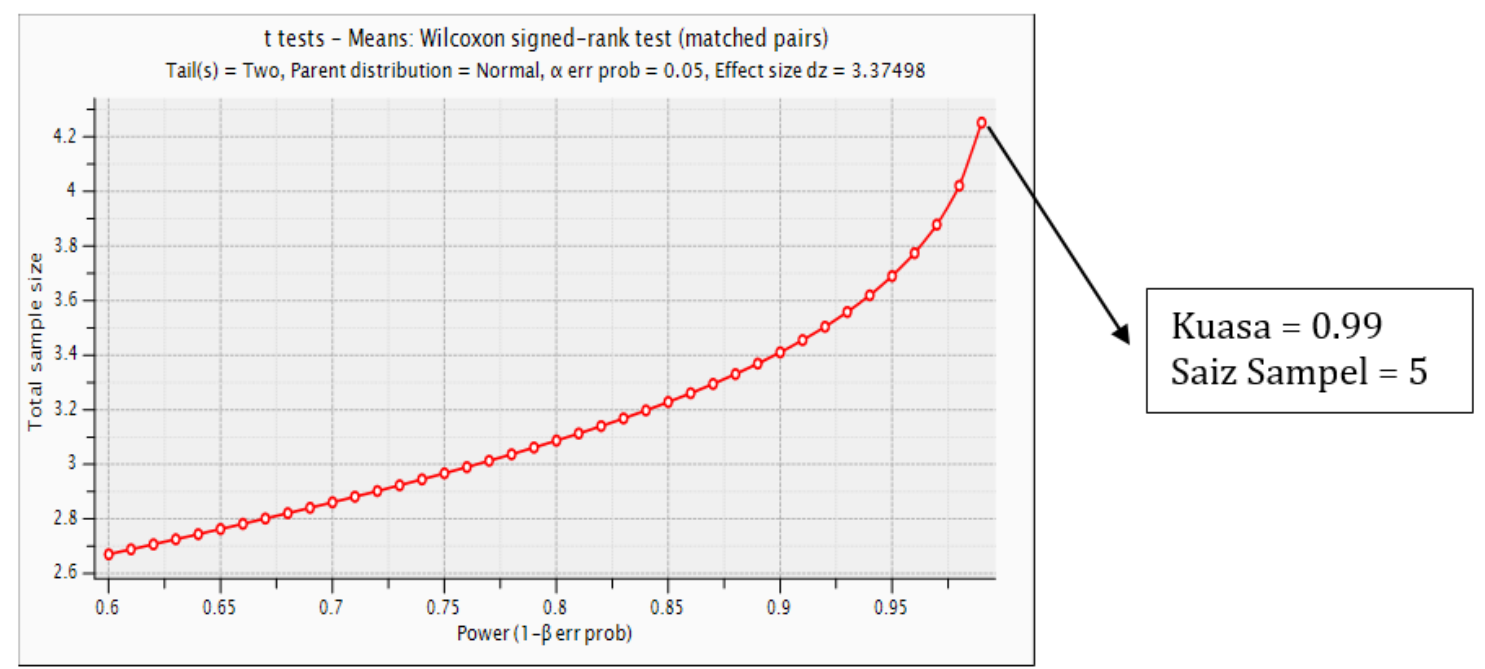

Rajah 13: Plot analisis statistik kuasa apriori motivasi 


\section{Perbincangan Dapatan Kajian}

Aktiviti-aktiviti pembelajaran yang tersedia sebanyak lapan aktiviti adalah mengikut garis panduan Dokumen Standard Kurikulum dan Pentaksiran (DSKP) bagi topik Teorem Pitagoras untuk subjek Matematik. DSKP ini merupakan garis panduan tahap isi kandungan sesuatu matapelajaran yang telah disediakan oleh Kementerian Pendidikan Malaysia (KPM). Keseluruhan aktiviti ini telah lengkap dan mencangkupi objektif dan hasil pembelajaran untuk topik Teorem Pitagoras. Untuk fasa inkuiri, muridmurid akan melalui lima fasa iaitu penglibatan(engage), penerokaan(explore), penerangan(explain), penghuraian (elaborate) dan penilaian (evaluate) untuk memastikan penggunaan blog reflektif melalui kaedah inkuiri ini memberikan kesan kepada murid-murid sebelum dan selepas menggunakannya. Setiap fasa telah disuntik dengan aktiviti-aktiviti yang bersifat autentik.

Dapatan kajian ini menunjukkan bahawa terdapat perbezaan yang signifikan terhadap pencapaian dan motivasi murid apabila menggunakan blog reflektif melalui kaedah inkuiri. Tahap motivasi bagi keempat-empat komponen iaitu komponen perhatian, relevan, keyakinan dan kepuasan didapati meningkat secara ketara berdasarkan perbezaan nilai min pasca dan pra setelah melalui proses pembelajaran menerusi blog reflektif. Kebanyakan murid telah menyatakan bahawa mereka faham dengan jelas untuk menyiapkan tugasan yang diberikan melalui blog reflektif. Ini menunjukkan bahawa kegiatan pembelajaran yang sedang diikuti oleh murid yang berkenaan adalah bermanfaat bagi mereka kerana ia seiring dengan kehendak pembelajaran. Ini disokong oleh murid melalui respon mereka yang sangat positif untuk bahagian perkaitan dan pengetahuan. Menurut Mekka Madaina Jamil (2019) motivasi sangat berkait rapat dengan tujuan. Justeru, bagi memaksimakan impak komponen perhatian, relevan, keyakinan dan kepuasan dalam matapelajaran matematik, guru hendaklah menyediakan sebaik mungkin instrumen pedagogi yang berkualiti yang mampu memberi lebih banyak ruang kepada murid untuk lebih kreatif. Tambahan lagi, Bai et al. (2012) turut menggalakkan guru-guru untuk mengutarakan kes-kes nyata yang mungkin dilalui oleh kehidupan harian murid yang berhubung kait secara langsung dengan konsep matematik kerana ia dapat menarik minat murid dan menjadikan sesi pembelajaran lebih bermakna. Hal ini juga telah terbukti melalui respon murid yang mana mereka juga ada menyatakan bahawa penyampaian maklumat di blog guru secara bergambar dalam bentuk penceritaan yang disertakan dengan ilustrasi yang menarik dapat menarik minat mereka. Melalui ekspresi mereka didalam penulisan refleksi telah menyatakan perkara-perkara yang menarik minat mereka untuk melalui fasa-fasa inkuiri semasa berblog. Sebagai contoh:

"perkara menarik pada blog kali ini ialah ilustrasi dan gambar yang ada di blog guru. Ia telah memudahkan saya untuk menyelesaikan tugasan kali ini" dan "blog ini menarik kerana guru saya mempersembahkan soalan menggunakan dialog dan gambar dengan jelas"

Berkenaan dengan pencapaian murid, hasil pencapaian murid selepas penggunaan blog reflektif didapati telah meningkat daripada pencapaian mereka sebelum penggunaan blog reflektif ini. Seramai 19 orang murid telah berjaya medapat gred A dan kebanyakkan mereka telah menyatakan bahawa mereka dapat memahami dengan lebih jelas tentang untuk menyelesaikan latihan yang diberi. Kebanyakkan mereka juga menyatakan bahawa pengetahuan sedia ada yang telah mereka pelajari sangat membantu mereka disamping pengetahuan baru di dalam blog reflektif ini yang juga telah memangkin kepada peningkatan pencapaian mereka. Kenyataan ini juga disokong oleh Beyer (2008) bahawa gaya pemikiran dan pengetahuan sangat mempengaruhi kepada pencapaian murid-murid dalam pembelajaran. Hal ini juga telah terbukti melalui respon murid yang menyatakan bahawa latihan yang diberikan di blog reflektif sangat senang dan mudah difahami. Contohnya:

"pengetahuan sedia ada sangat membantu saya menyiapkan aktiviti dengan lancar dan mudah" dan "pengetahuan yang diberi oleh guru juga telah membantu saya menyelesaikan praktis yang diberi"

Justeru, kemahiran, pencapaian dan motivasi mereka dalam pengajaran dan pembelajaran menerusi blog akan meningkat. Kepentingan untuk menghasilkan persekitaran pembelajaran menggunakan blog telah diakui secara teori dan praktikal dalam pedagogi pendidikan. Namun, jika dilihat dari aspek pelaksanaan dan keberkesanannya masih perlu dikaji dan difahami terutama kesannya dalam proses pengajaran dan pembelajaran pada masa kini. Aspek ini sangat penting dan memerlukan satu kajian secara telus dan 
empirikal bagi menjadi kayu ukur kepada kejayaan sesebuah sistem pengajaran dan pembelajaran sebenar. Keberkesanan kajian ini dapat dilihat jika pembentukan pengetahuan yang bernilai berkadar langsung dengan kesan teknologi yang diadaptasikan. Oleh itu, penggunaan blog reflektif melalui kaedah inkuiri berperanan penting untuk meningkatkan pencapaian dan motivasi murid-murid tingkatan empat untuk topik teorem pitagoras.

\section{Kesimpulan}

Secara kesimpulannya, kajian ini telah melaporkan bahawa terdapat kesan yang signifikan penggunaan blog refektif melalui kaedah inkuiri terhadap pencapaian dan motivasi. Kepentingan untuk menghasilkan persekitaran pembelajaran menggunakan blog telah diakui secara teori dan praktikal dalam pedagogi pendidikan. Oleh yang demikian, pengkaji mengharapkan bahawa peranan daripada semua pihak perlu bagi memastikan penggunaan blog reflektif melalui kaedah inkuiri dapat memberikan impak yang positif terhadap keberkesanan, pelaksanaan, proses dan hasil pembelajaran untuk peningkatan pencapaian dan motivasi murid-murid. Aspek ini sangat penting dan memerlukan satu kajian secara telus dan empirikal bagi menjadi kayu ukur kepada kejayaan sesebuah sistem pengajaran dan pembelajaran sebenar. Keberkesanan kajian ini dapat dilihat jika pembentukan pengetahuan yang bernilai serta tahap motivasi berkadar langsung dengan kesan teknologi yang diadaptasikan. Oleh itu, penggunaan blog reflektif melalui kaedah inkuiri berperanan penting untuk meningkatkan pencapaian dan motivasi murid tingkatan empat untuk topik teorem pitagoras. Keadaan pedagogi sebegini juga perlu berlangsung secara berterusan dalam suasana pembelajaran secara maya seiring dengan penerapan elemen teknologi maklumat untuk pembelajaran abad ke-21. Peranan daripada semua pihak turut diperlukan bagi memastikan penggunaan blog reflektif melalui kaedah inkuiri dapat memberikan impak yang positif terhadap keberkesanan, pelaksanaan, proses dan hasil pembelajaran untuk peningkatan pencapaian dan motivasi murid.

\section{Rujukan}

Auster, E. R., \& Wylie, K. K. (2006). In the Classroom : https://doi.org/10.1177/1052562905283346

Bai, H., Pan, W., Hirumi, A., \& Kebritchi, M. (2012). Assessing the effectiveness of a 3-D instructional game on improving mathematics achievement and motivation of middle school students. British Journal of Educational Technology, 43(6), 993-1003. https://doi.org/https://doi.org/10.1111/j.1467-8535.2011.01269.x

Beyer, B. K. (2008). What Research Tells Us about Teaching Thinking Skills. The Social Studies, 99(5), 223-232. https://doi.org/10.3200/TSSS.99.5.223-232

Bybee, R. W., Taylor, J. A., Gardner, A., Van, P., Powell, J. C., Westbrook, A., Landes, N., Spiegel, S., Stuhlsatz, M. M., Ellis, A., Thomas, H., Bloom, M., Moran, R., Getty, S., \& Knapp, N. (2006). The BSCS 5E Instructional Model : Origins and Effectiveness A Report Prepared for the Office of Science Education by 5415 Mark Dabling Boulevard. Science Education, June.

Ciampa, K., \& Gallagher, T. L. (2015). Blogging to enhance in-service teachers??? professional learning and development during collaborative inquiry. Educational Technology Research and Development, 63(6), 883-913. https://doi.org/10.1007/s11423-015-9404-7

Cooper, A. (2012). Today's Technologies Enhance Writing in Mathematics. The Clearing House: A Journal of Educational Strategies, Issues and Ideas, 85(2), 80-85. https://doi.org/10.1080/00098655.2011.624394

Frye, E. M., Trathen, W., \& Koppenhaver, D. A. (2010). Internet Workshop and Blog Publishing: Meeting Student (and Teacher) Learning Needs to Achieve Best Practice in the Twenty-FirstCentury Social Studies Classroom. The Social Studies, 101(2), 46-53. https://doi.org/10.1080/00377990903284070

Garcia, I., \& Pacheco, C. (2013). A constructivist computational platform to support mathematics education in elementary school. Computers and Education, 66, 25-39. https://doi.org/10.1016/j.compedu.2013.02.004

Hargrove, R. A. (2013). Assessing the long-term impact of a metacognitive approach to creative skill 
development. International Journal of Technology and Design Education, 23(3), 489-517. https://doi.org/10.1007/s10798-011-9200-6

Jackling, B., Natoli, R., Siddique, S., \& Sciulli, N. (2015). Student attitudes to blogs: a case study of reflective and collaborative learning. Assessment \& Evaluation in Higher Education, 40(4), 542 556. https://doi.org/10.1080/02602938.2014.931926

Keller, J. (2010). Motivational Design for Learning and Performance: The ARCS Model Approach. In Motivational Design for Learning and Performance: The ARCS Model Approach. https://doi.org/10.1007/978-1-4419-1250-3

Krathwohl, D. R. (2002). A Revision of Bloom's Taxonomy: An Overview. Theory Into Practice, 41(4), 212-218. https://doi.org/10.1207/s15430421tip4104_2

Landis, J., \& Koch, G. (1977). The Measurement of Observer Agreement for Categorical Data. Biometrics, 33(1), 159-174. https://doi.org/10.2307/2529310

Loving, C. C., Schroeder, C., Kang, R., Shimek, C., \& Herbert, B. (2007). Blogs : Enhancing Links in a Professional Learning Community of Science and Mathematics Teachers. 7, 178-198.

McPherson, S. (2009). A Dance with the Butterflies: A metamorphosis of teaching and learning through technology. Early Childhood Education Journal, 37(3), 229-236. https://doi.org/10.1007/s10643009-0338-8

Mekka Madaina Jamil. (2019). Optimalisasi Model ARCS Dalam Pembelajaran Saintifik Untuk Meningkatkan Motivasi Belajar Peserta Didik Pada Peminatan Mata Pelajaran Geografi Di Kelas Matematika Ilmu Alam. IJIS Edu: INDONESIAN JOURNAL OF INTEGRATED SCIENCE EDUCATION, 1(1), 7-24. http://ejournal.iainbengkulu.ac.id/index.php/ijisedu/article/view/1401

Mohamed, N., Jamil, N. A. A., \& Karim, N. S. A. (2013). Teaching styles and attitudes toward blog use among Malaysian school teachers. International Journal of Technology, Knowledge and Society, $8(4), 1-11$.

Morgan, H. (2015). Creating a Class Blog: a Strategy That Can Promote Collaboration, Motivation, and Improvement in Literacy. Reading Improvement, 52(1), 27-31. http://search.ebscohost.com/login.aspx?direct=true \&db=a9h\&AN=101674122\&site=eds-live

Royer, R. D. (2008). Educational Blogging : Going Beyond Reporting , Journaling , and Commenting to Make Connections and Support Critical Thinking.

Scott, K. S., Sorokti, K. H., \& Merrell, J. D. (2016). Learning "beyond the classroom" within an enterprise social network system. The Internet and Higher Education, 29, 75-90. https://doi.org/10.1016/j.iheduc.2015.12.005

Stoyle, K. L., \& Morris, B. J. (2017). Blogging mathematics: Using technology to support mathematical explanations for learning fractions. Computers and Education, 111, 114-127. https://doi.org/10.1016/j.compedu.2017.04.007

Thomas, S. (2017). Journalogue: Voicing student challenges in writing through a classroom blog. Educational Technology and Society, 20(1), 112-122.

Villardón-Gallego, L. (2016). Inquiry-based Learning in Pre-service Training for Secondary Education Counselors. Procedia - Social and Behavioral Sciences, 217, 65-73. https://doi.org/10.1016/j.sbspro.2016.02.028

Wang, S. M., Hou, H. T., \& Wu, S. Y. (2017). Analyzing the knowledge construction and cognitive patterns of blog-based instructional activities using four frequent interactive strategies (problem solving, peer assessment, role playing and peer tutoring): a preliminary study. Educational Technology Research and Development, 65(2), 301-323. https://doi.org/10.1007/s11423-0169471-4 